\title{
Article \\ Omni-Channel Customer Experience (In)Consistency and Service Success: A Study Based on Polynomial Regression Analysis
}

\author{
Wei Gao ${ }^{1}$ and Hua Fan ${ }^{2, *}$ \\ 1 College of Economics and Management, Southwest University, Chongqing 400715, China; \\ gaoweibaggio@swu.edu.cn \\ 2 School of Business and Management, Shanghai International Studies University, Shanghai 200083, China \\ * Correspondence: 02748@shisu.edu.cn
}

check for updates

Citation: Gao, W.; Fan, H. Omni-Channel Customer Experience (In)Consistency and Service Success: A Study Based on Polynomial Regression Analysis. J. Theor. Appl. Electron. Commer. Res. 2021, 16, 1997-2013. https://doi.org/ 10.3390/jtaer16060112

Academic Editors: Gang Li, T. C. Edwin Cheng and Tao Zhang

Received: 3 June 2021

Accepted: 23 July 2021

Published: 25 July 2021

Publisher's Note: MDPI stays neutral with regard to jurisdictional claims in published maps and institutional affiliations.

Copyright: (c) 2021 by the authors. Licensee MDPI, Basel, Switzerland. This article is an open access article distributed under the terms and conditions of the Creative Commons Attribution (CC BY) license (https:// creativecommons.org/licenses/by/ $4.0 /)$.

\begin{abstract}
Drawing on expectation disconfirmation theory, this study explores the dyadic nature of omni-channel consistency on customer experience. Specifically, we propose a conceptual model that focuses on a brand's offline channel customer experience relative to that of its online channel, and test the influences of customer experience (in)consistency on customer satisfaction, which then improves repurchase intention and word-of-mouth. The results of polynomial regressions on 265 survey respondents indicate that given omni-channel customer experience inconsistency, customers prefer consistent online and offline experiences. For omni-channel consistency at lower levels of customer experience quality, customers prefer consistency at higher levels of quality. For omni-channel inconsistency where offline customer experience quality is lower than that online, customers prefer omni-channel inconsistency, where offline customer experience quality is higher than that online. These findings produce not only theoretical contributions but also insightful suggestions for how customer experience can be taken into consideration in the promotion of a brand's omni-channel service success.
\end{abstract}

Keywords: customer experience; omni-channel consistency; expectation-disconfirmation theory; polynomial regression

\section{Introduction}

The traditional e-commerce business model becomes commoditized, and digital attackers are experimenting with new retail models in which the typical customer journey is likely to be a mix of offline and online, or omni-channel [1-3]. Customers may evaluate products online and buy offline, or touch and feel offline and shop online, or even shift constantly between the offline channel and online channel [4,5]. Omni-channel practice has developed rapidly, with at least 60 percent of shoppers now excited about omni-channel services; this is particularly the case in China, where the overwhelming majorities of shoppers-85 percent-are already omni-channel customers [6]. However, some of these omni-channel customers may suffer from imbalanced resources or inconsistent treatment quality across different channels. This highlights the vital challenge to brands and retail companies of shaping and managing the omni-channel customer experience [7-9].

Customer experience is defined as a customer's holistic judgment of a firm's offerings during indirect and direct encounters with the firm [5]. Engendering optimal customer experience is vital for a firm to acquire successful marketing outcomes, and increase the likelihood of success [10-13]. Thus, building a superior customer experience has become an important leading management objective $[9,14-16]$. Optimizing customer experience lies at the heart of both physical retailing [17,18] and virtual retailing services [19-22]. Accordingly, the effectiveness of customer experience is becoming an essential and popular research topic in the retailing and services literature [14,23-25]. 
Despite these fertile studies, research on customer experience has three main gaps. First, omni-channel businesses have become more and more common, as many customers alternate between offline channel and online channel [26]. Thus, omni-channel businesses represent an unprecedented opportunity for brands and retail companies to leverage synergies between channels to synchronize customers' multichannel experiences [27]. Great efforts have been made to examine customer experience in both the offline channel environments (in the physical retailing literature) and online channel settings (in the virtual retailing literature), yet few studies have integrated offline and online research perspectives or developed an omni-channel understanding (Research Gap 1) of customer experience $[5,7,28]$.

Second, stemmed from channel integration research, omni-channel consistency has been well-defined as the integrated interaction quality which involves two dimensions: content consistency and process consistency $[29,30]$. Based on these two dimensions, extant research has shed light on various types of channel consistency, such as promotion congruence [31], visual e-channel congruence [32], image congruity [33], cross-channel congruence [1], and retailer-brand incongruity [34]. Although customer experience captures a holistic judgement of interaction quality, and it is becoming the norm for customers to expect a consistent shopping experience across different retail channels [28], there has been little research on the consistency of multichannel customer experiences [35]. Further, although customers experience offline and online channels separately, without exception, prior studies applied unilateral and holistic measures, and none used a dyadic measurement methodology for consistency (Research Gap 2) in comparing offline customer experiences with online ones [20].

Third, the inconsistency between multichannel touch points can decrease customers' omni-channel shopping value, cause confusion and incomprehension, and even result in negative emotions including frustration, anger and disappointment [1]. Expectation disconfirmation theory (EDT) proposes that these undesirable evaluations result from one of the two directions of inconsistency between experiences and expectations-that is, positive inconsistency or negative inconsistency [36,37]. Despite a great deal of research have identified the severe consequences of multichannel inconsistency [23,34], there is limited research on the directions of this inconsistency (i.e., whether offline customer experiences surpass online customer experiences, and vice versa) in the customer experience literature (Research Gap 3).

To fill up the above research gaps, this research uses the EDT lens to scrutinize the dyadic nature of omni-channel customer experiences; that is, the "(in)consistency" between offline customer experience and online customer experience. Specifically, we intend to explore two research questions, as follows. (1) How does (in)consistency in omnichannel customer experiences influence brands' and retail companies' service success? (2) What kind of inconsistency in omni-channel customer experiences should brands and retail companies address to avoid service failure? In answering these research questions, the present study makes contributions to current literatures in three aspects. First, the current study contributes to the customer experience studies via introducing an omnichannel perspective that bridges customer experience research in offline and online retailing environments. Second, this study also contributes to the channel consistency research by using an indirect research view to capture customer experience consistency. Third, we contribute to expectation disconfirmation theory by comparing the influences of the two inconsistency directions. Thus, on the one hand, this study extends the theoretical perspective on the omni-channel consistency of customer experiences; on the other hand, it provides advices for retail channel design in customer experience management. 


\section{Literature Review}

\subsection{Omni-Channel Consistency}

The concept of channel consistency has been well acknowledged, and researchers have suggested that customers are likely to move across multiple retail channels and to expect a consistent shopping journey [23,27]. Consistent omni-channel shopping provides customers with options to purchase at any time and place, thus inducing positive outcomes such as customer loyalty [38], satisfaction [39], attitudes to retailers [40], and consumption [29].

Previous research on omni-channel consistency often focuses on two dimensions, content and process consistency [41]. The prior refers to "the consistency of information features across different channels" [29], while the latter represents "the degree of consistency of relevant and comparable process attributes across channels" [30]. Although some extant literature has implied that omni-channel retailers ought to provide consistent customer experience, there has been a limited number of studies on omni-channel customer experience consistency [28].

During the interactions with a retailer's service delivery channels, a customer buys products or receives service from the retailer's offline or online stores, thus forming offline and online customer experiences [19]. We therefore pay attention to the dyadic nature of omni-channel consistency, and propose that customers desire online experiences that are consistent with offline ones [23]. In specific, following Gao et al. [28] conceptualization, we define omni-channel customer experience (in)consistency as a (discrepancy) congruency between the offline and online customer experience. Consistency occurs when a customer's offline customer experience is of equivalent quality with his/her online customer experience. Inconsistency exists when the customer's offline customer experience is either worse or better than his/her online customer experience.

\subsection{Omni-Channel Customer Experience}

Defined as customers' subjective responses to the contact with a company, customer experience captures their general assessments of a retailers' services, brands, and products $[5,14]$. Customer experience has been an enduring research realm for both academics and practitioners because it is an important antecedent of customer retention [28], loyalty [42] and ultimate behavior intention [43]. Therefore, superior customer experience has become a powerful tool for retailers to secure competitive advantage.

However, most of the previous studies on customer experience have shed light on either online contexts or offline contexts; limited attention has been paid to the omni-channel retailing environment [7]. In fact, customer experience has been so revolutionized by the emerging mobile technologies that the borders between channels are fading away [23]. Customers nowadays have moved from purchase processes in sole channel to purchase journeys where multiple channels are seamlessly and interchangeably used [4,44]. For example, a customer may look for products on the internet and goes to the brick-andmortar store to confirm the information and purchase (i.e., webrooming) [45]; he/she may also check a product at the physical store and go online to place an order (i.e., showrooming) [46]. Therefore, an important issue remaining under-explored is how offline and online customer experience simultaneously influence a customer's psychological and behavioral response in omni-channel retailing contexts [28]. Our proposed framework (see Figure 1) thus explains how various combinations of online and offline customer experiences are mediated by customers' holistic satisfaction and how they drive brands' service success. 


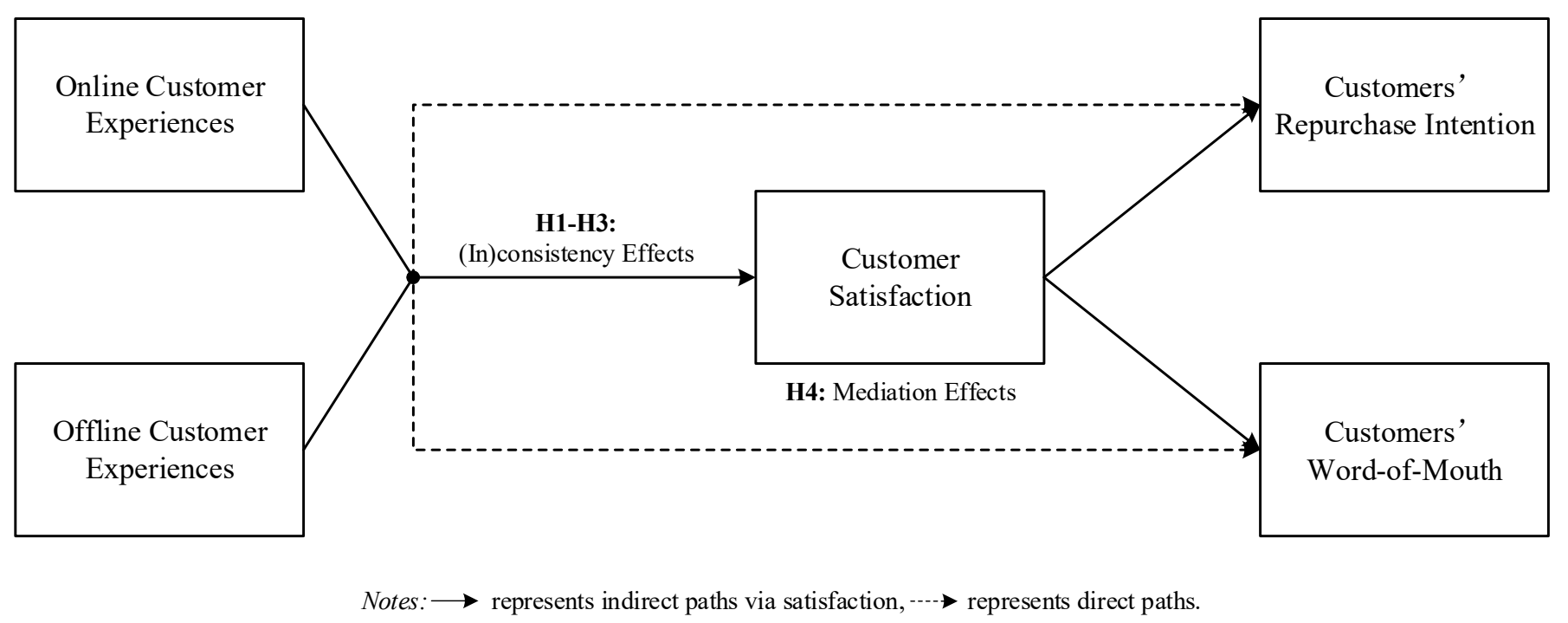

Figure 1. Conceptual Model.

\section{Hypotheses}

Before developing the corresponding hypotheses, to better pinpoint the different combinations of online and offline customer experiences, we propose a two-by-two matrix (see Figure 2) that juxtaposes the quality of customer experiences (i.e., high vs. low) with the source of those customer experiences (i.e., online channel vs. offline channel). As indicated by the matrix, quadrant 1 represents customer experiences consistent at high levels of quality, quadrant 2 represents customer experiences consistent at low levels of quality, quadrant 3 represents customer experiences inconsistency where online customer experiences are better than offline ones, and quadrant 4 represents customer experiences inconsistency where offline customer experiences are better than online ones.

We use EDT to provide theoretical support on the potential outcomes of consistency and inconsistency. EDT has roots in the marketing literature and has received vast attention in consumer behavior research $[36,37,47]$. EDT research address that customers obtain satisfaction through following the causal flow: first, forming initial beliefs and expectations when starting to use the product or service [48]; second, cognitively comparing performance during a subsequent period against initial expectations and calculating the (dis)confirmation [47]; and finally, determining their satisfaction level according to "a combination of expectations and disconfirmation" [37] (p. 283). Based on the EDT, expectation represents a set of pre-exposure beliefs about the product or service [37], and disconfirmation is "a subjective post-usage comparison that can result in one thinking performance was better, the same as, or worse than expected" [49] (p. 89).

Following this logic, we propose that in an omni-channel retailing context, a customer's expectation is a consistent, interchangeable, and seamless shopping journey $[1,23]$. When the customer's experience on the second channel exceeds (falls short of) his/her experience on the first channel, positive (negative) disconfirmation occurs [50]. In the present study, we use the notions of "expectation-(dis)confirmation" to differentiate customer experience consistency from inconsistency (i.e., quadrants 1 and 2 vs. quadrants 3 and 4). The EDT also posits that outcome evaluations are a function of disconfirmation magnitude between expectations and experiences such that satisfaction increases as the disconfirmation magnitude decreases and the degree of confirmation increases [36]. In this research, we use the notions of "disconfirmation magnitude" to differentiate the two scenarios of consistency (i.e., quadrant 1 vs. quadrant 2 ) and the two directions of inconsistency (i.e., quadrant 3 vs. quadrant 4 ). 


\begin{tabular}{|c|c|c|c|}
\hline & & \multicolumn{2}{|c|}{ Offline Customer Experiences } \\
\hline & & $\begin{array}{l}\text { High quality } \\
\text { Customers rate the quality of offline } \\
\text { channel experiences as excellent and } \\
\text { superior }\end{array}$ & $\begin{array}{l}\text { Low quality } \\
\text { Customers rate the quality of offline } \\
\text { channel experiences as mediocre or } \\
\text { even disappointing }\end{array}$ \\
\hline \multirow{2}{*}{ 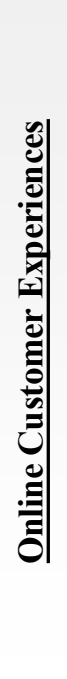 } & $\begin{array}{l}\text { High quality } \\
\text { Customers rate the quality of online } \\
\text { channel experiences as excellent and } \\
\text { superior }\end{array}$ & $\begin{array}{c}\text { Expectation-confirmation } \\
\text { Customers' expectation of a } \\
\text { consistent shopping journey fulfilled } \\
\text { by both excellent online and offline } \\
\text { experiences } \\
\text { (Quadrant 1) }\end{array}$ & $\begin{array}{l}\text { Expectation-disconfirmation } \\
\text { Customers' expectation of a } \\
\text { consistent shopping journey } \\
\text { unfulfilled due to superior online } \\
\text { experiences than offline ones } \\
\text { (Quadrant 3) }\end{array}$ \\
\hline & $\begin{array}{l}\text { Low quality } \\
\text { Customers rate the quality of online } \\
\text { channel experiences as mediocre or } \\
\text { even disappointing }\end{array}$ & $\begin{array}{l}\text { Expectation-disconfirmation } \\
\text { Customers' expectation of a } \\
\text { consistent shopping journey } \\
\text { unfulfilled due to superior offline } \\
\text { experiences than online ones } \\
\text { (Quadrant 4) }\end{array}$ & $\begin{array}{l}\text { Expectation-confirmation } \\
\text { Customers' expectation of a } \\
\text { consistent shopping journey fulfilled } \\
\text { by both mediocre online and offline } \\
\text { experiences } \\
\text { (Quadrant } 2 \text { ) }\end{array}$ \\
\hline
\end{tabular}

Figure 2. Two-by-two matrix juxtaposing qualities with sources of customer experiences.

\subsection{Differentiating Customer Experience Consistency from Inconsistency}

Applying the tenets of EDT to differentiate customer experience consistency from inconsistency, expectation confirmation increases as customers' online and offline ratings of experiences become increasingly similar (i.e., high-high and low-low ratings: quadrants 1 and 2 of Figure 2), and expectation disconfirmation increases as customers' online and offline ratings of experiences diverge (i.e., high-low and low-high ratings: quadrants 3 and 4 of Figure 2). When customers perceive both online and offline experiences to be of a high quality, excellent and superior omni-channel customer experiences are consistent. Similarly, when customers perceive both online and offline experiences to be of a low quality, mediocre or even disappointing omni-channel customer experiences are consistent. However, when customers' expectation of a consistent shopping journey is unrealized, inconsistency occurs between the offline and online customer experiences.

Based on EDT, customers are more likely to develop satisfaction as the consistency of customer experiences increases. Before engaging a brand's services through either online or offline retail channels, customers usually develop an initial expectation that the services from both channels ought to be seamless and consistent $[1,23]$. Through navigating the different purchase stages of the customer journey, isolated experiences pertaining to online and offline channels are built up [5]. As the isolated online and offline customer experiences are consistent (regardless of whether they are consistently high quality or low quality), customers will cognitively recognize the consistency, and their initial expectations will be met. Thus, customer experience consistency has important consequences for customer satisfaction, as satisfaction follows when customers' expectations are met [37]. 
EDT also suggests that customer satisfaction will decrease as the inconsistency of customer experiences increases. EDT posits that any disconfirmation between experiences and expectations, whether negative or positive, will produce negative resulting outcome evaluations [36]. When the inconsistency between offline and online customer experience increases, a customer's cognitive cost and perceived risk are also intensified [28]. On the one hand, the customer needs to pay more cognition effort to switch among inconsistent channels [51]; on the other hand, the purchase task becomes more ambiguous and riskier as the information displayed by different channels becomes asymmetric [52]. Therefore, even when the experience on the latter channel exceeds the experience on the former channel, disconfirmation still exists where customers' expectations (i.e., a consistent shopping journey) are not met, which may result in psychological discomfort for customers, affecting their beliefs, attitudes, and actions [53]. This psychological discomfort could trigger customers' negative emotional response [21,37]. Hence, this study proposes that:

Hypothesis 1 (H1). The more consistency (compared with inconsistency) between online customer experiences and offline customer experiences, the greater the customer satisfaction.

\subsection{Differentiating the Two Scenarios of Customer Experience Consistency}

According to EDT, under the condition of customer experience consistency (i.e., highhigh vs. low-low ratings: quadrant 1 vs. quadrant 2 of Figure 2), the quality of customer experiences should be positively related to customer satisfaction. Customers expect exceptional online experiences [20]. A compelling online experience (e.g., offering location-based content by the use of GPS) increases customers' engagement, leads them to spend more time on the brand's website or mobile app, and facilitates the usage of online channels [19,54]. Customers also seek exceptional offline experiences [18]. A pleasurable offline experience can induce customers to try products, taste in-store samples, and, most importantly, to shop [55].

Further, positive experiences, whether online or offline, will increase customers' confidence that they are not being taken advantage of and that the brand is concerned about their welfare [56]. Such perceptions of honesty, benevolence, and competence by the brand will lead to higher levels of customer satisfaction [57]. Therefore, brands that offer both online and offline services of outstanding quality can meet customers' expectations of consistent and excellent shopping experiences. Brands that provide ordinary omni-channel services can meet customers' expectation of a consistent shopping journey but not their expectation of an excellent shopping experience. EDT posits that outcome evaluations are a function of the size of the gap between expectations and experiences such that satisfaction increases as the degree of confirmation increases [27,36]. Therefore, when online and offline customer experiences are consistently high quality than when they are consistently low quality, the customer satisfaction will be higher. Thus, we propose this:

Hypothesis 2 (H2). Customer satisfaction is higher when online and offline customer experiences are consistent at a higher level than when online and offline customer experiences are consistent at a lower level.

\subsection{Differentiating the Two Directions of Customer Experience Inconsistency}

When customers do not have consistent customer experiences between the online shopping channel and the offline retail channel, two outcomes are seemingly plausible (i.e., high-low vs. low-high ratings: quadrant 3 vs. quadrant 4 of Figure 2). First, many firms are now devoting a large marketing investment to build customer experience via mobile applications and websites [19], and every aspect of the customer journey, such as product information search and purchase transaction, could be conveniently realized through the online retail channel [20]. Customer perceptions of online channel experiences may then dominate, rendering offline customer experiences irrelevant. Alternatively, because online shopping is viewed by customers as impersonal and lacking scalability [54], 
given customers' requirements for a sensory evaluation of the product, interpersonal communication, and instant gratification [58], customer perceptions of offline channel experiences may be a stronger driver of satisfaction.

In discussing the effects of disconfirmed expectations, EDT researchers argue that a negative psychological state of cognitive dissonance occurs when individuals expect a certain event, but they experience something different [59]. If the disconfirmation magnitude is small, such as in the person's zone of tolerance, they will adjust their expectations to reduce cognitive dissonance [60]. However, if the magnitude is large and outside the person's zone of tolerance, cognitive dissonance will trigger an irreversible negative effect on service outcomes [36].

Customers prefer the retail channel that provides the highest value, such as the best information, detailed and accurate product descriptions, and interpersonal interactions [1]. In the offline stores, customers can physically touch the product, directly assess the product quality, and instantly receive input from salespersons, which is satisfying to them. Customers thus put more emphasis on and have higher expectations for offline shopping [58]. Therefore, a poor offline customer experience is more unacceptable for customers than a poor online customer experience. Perceiving a better offline customer experience than online customer experience is thus more likely to remain within the zone of tolerance.

Customers are also inclined to select a retail channel that minimizes their time, effort, and psychic costs [61]. As the increasing adoption of mobile phone technologies, these expectations are much easier to be realized in online retail channels but are challenging for physical stores [1]. That is, customers expect offline stores to provide a much better customer experience than online stores because they spend more time, effort, and psychic costs on offline channels. Therefore, given the lower levels of online experience quality, a poor-quality offline customer experience is more likely to fall outside customers' zone of tolerance. As such, customer satisfaction is lower when a customer perceives the online customer experience to be better than the offline one compared to the reverse. Therefore, this study proposes this:

Hypothesis 3 (H3). Customer satisfaction is lower when online customer experiences are better than offline experiences compared to the reverse.

\subsection{Customer Satisfaction as Mediator of the Effect of (In)Consistency on Service Success}

EDT suggests that as a function of customers' prior expectations and disconfirmation, satisfaction can influence their behaviors, including continuance intention and repurchase intention [36,37]. Customers' perception of a brand as a source of consistent and compelling experiences can increase the perceived value of the brand, which may remain fresh in the customers' memory until their next consumption [17]. Thus, customer experience (in)consistency may have impact on the service value and repurchase intention [11]. In addition, a high level of customer experience can promote customers to engage in positive word-of-mouth [18]. It represents the customers' willingness to share their experiences with others and recommend that others use or switch to the particular brand [54]. After perceiving high levels of brand value from their consistent shopping journey, customers are motivated to create positive attitudes toward the brand (e.g., satisfaction) that may generate positive word-of-mouth, such as advocating for the brand's consistent omnichannel services, high product quality, or acceptable shopping costs [62]. As such, this study proposes this:

Hypothesis 4 (H4). Customer satisfaction mediates the relationships between customer experience (in)consistency and customers' (a) repurchase intention and (b) word-of-mouth. 


\section{Research Methodology}

\subsection{Sample}

We examined the hypotheses by conducting an online survey and collecting omnichannel customers' data. The online questionnaires were distributed through a professional online survey platform, and the respondents were recruited with a snowball sampling method. To ensure the quality of the questionnaires, six doctoral students in the related research field checked the questions, and we modified the questionnaires according to their suggestions before the online survey. At the beginning of the survey questionnaire, we included a filtering question asking whether respondents had shopping experience with one brand's online and offline stores. Only respondents who had prior online and offline shopping experiences with the same brand could participate in our survey. Then, the qualified respondents were invited to fill out the questionnaire according to their online and offline shopping experiences with the brand which they chose. Finally, we obtained 265 useable responses for data analysis. Of the 265 respondents, 140 were female. Majorities were aged between 26 and 30 years old $(60 \%)$ and held a bachelor's degree $(43.8 \%)$. In terms of monthly income, $32.1 \%$ of respondents earned between 3001 and 6000 . The more detailed demographic characteristics was presented in Table 1.

Table 1. Demographic characteristics.

\begin{tabular}{lll}
\hline & Number & Percent (\%) \\
\hline Gender & 125 & 47.2 \\
Male & 140 & 52.8 \\
Female & & \\
Age (years) & 11 & 4.2 \\
$\leq 20$ & 69 & 26.0 \\
$21-25$ & 159 & 60.0 \\
$26-30$ & 19 & 7.2 \\
31-35 & 7 & 2.6 \\
$\geq 36$ & & \\
Education & 62 & 23.4 \\
Below bachelor & 116 & 43.8 \\
Bachelor & 71 & 26.8 \\
Master & 16 & 6.0 \\
PhD & & \\
Monthly income (yuan) & 69 & 26.0 \\
$\leq 3000$ & 85 & 32.1 \\
3001-6000 & 71 & 26.8 \\
6001-9000 & 21 & 7.9 \\
$9001-12,000$ & 19 & 7.2 \\
$\geq 12,001$ & &
\end{tabular}

\subsection{Measurement and Validity}

All of our measurements were adapted from prior research. Three items used to measure offline and online customer experience, were adapted from Kim and Choi [18]. Three items were adapted from Pérez and Rodriguez del Bosque [63] to measure customer satisfaction. Four items were adapted from Ranaweera and Karjaluoto [62] to measure word-of-mouth. A three-item scale used to measure repurchase intention were adapted from Khalifa and Liu [64]. A 7-point Likert scale was applied to evaluate all the items.

We performed a confirmatory factor analysis, and the results showed that our data has an adequate fit to the measurement model $\left(x^{2}=214.913, \mathrm{df}=94, \mathrm{RMSEA}=0.070\right.$, $\mathrm{CFI}=0.977$, TLI $=0.971$, SRMR $=0.029$ ). As Table 2 presented, the estimates of Cronbach's $\alpha$ and CR were higher than 0.7, suggesting good reliability [65]. The values of the AVE were above 0.5 , exhibiting good convergent validity [65]. As reported in Table 3, the square root of AVE value of each construct exceeded all correlations among constructs, indicating adequate discriminant validity. In addition, we followed Lindell and Whitney's [66] 
procedure to examine common method variance (CMV). As seen in Table 3, the lowest positive pairwise correlation was 0.002 . We adjusted the correlations based on this value, which can be regarded as a valid indicator of CMV [66]. The results showed that there is no prior significant correlation lost significance, which suggests that CMV is not likely to be a serious issue.

Table 2. Construct reliability and validity.

\begin{tabular}{lc}
\hline Constructs & Factor Loadings \\
\hline Online customer experiences $(\alpha=0.950, \mathrm{CR}=0.951, \mathrm{AVE}=0.865)$ & 0.922 \\
1. I would say that the experience at this brand's online shop is excellent & 0.934 \\
2. I believe that we get a superior experience at this brand's online shop & 0.934 \\
3. I think that the total experience procedure at this brand's online shop is excellent & 0.949 \\
Offline customer experiences $(\alpha=0.960, \mathrm{CR}=0.960, \mathrm{AVE}=0.889)$ & 0.950 \\
1. I would say that the experience at this brand's offline shop is excellent & 0.930 \\
2. I believe that we get a superior experience at this brand's offline shop & 0.947 \\
3. I think that the total experience procedure at this brand's offline shop is excellent & 0.925 \\
Customer satisfaction $(\alpha=0.956, \mathrm{CR}=0.956$, AVE $=0.878)$ & 0.939 \\
1. My decision to choose this brand was the right one & 0.956 \\
2. I feel happy about my decision to choose this brand & 0.961 \\
3. In general, I am satisfied with this brand & 0.895 \\
Repurchase intention $(\alpha=0.955, \mathrm{CR}=0.956$, AVE $=0.880)$ & 0.896 \\
1. Given the chance, I would consider purchasing products of this brand in the future & 0.949 \\
2. It is likely that I will actually purchase products of this brand in the near future & 0.939 \\
3. Given the opportunity, I intend to purchase products of this brand & 0.966 \\
Word-of-mouth $\alpha=0.967, \mathrm{CR}=0.967$, AVE $=0.880)$ & \\
1. I say positive things about this brand to other people & \\
2. I would recommend this brand to those who seek my advice about such matters & \\
3. I would encourage friends and relatives to use this brand & \\
4. I would post positive messages about this brand on an internet message board & \\
\hline
\end{tabular}

Table 3. Correlation Matrix $(n=265)$.

\begin{tabular}{lllllllll}
\hline Variables & $\mathbf{1}$ & $\mathbf{2}$ & $\mathbf{3}$ & $\mathbf{4}$ & $\mathbf{5}$ & $\mathbf{6}$ & $\mathbf{7}$ & $\mathbf{8}$ \\
\hline 1. Online customer experiences & $\mathbf{0 . 9 3 0}$ & & & & & & \\
2. Offline customer experiences & $0.538^{* *}$ & $\mathbf{0 . 9 4 3}$ & & & & & \\
3. Customer satisfaction & $0.415^{* *}$ & $0.299^{* *}$ & $\mathbf{0 . 9 3 7}$ & & & & \\
4. Repurchase intention & $0.360^{* *}$ & $0.359^{* *}$ & $0.449^{* *}$ & $\mathbf{0 . 9 3 8}$ & & & \\
5. Word-of-mouth & $0.528^{* *}$ & $0.298^{* *}$ & $0.637^{* *}$ & $0.454^{* *}$ & $\mathbf{0 . 9 3 8}$ & & & \\
6. Gender & 0.055 & 0.071 & $0.175^{* *}$ & 0.015 & 0.024 & - & & \\
7. Age & -0.020 & 0.016 & -0.010 & -0.014 & 0.002 & 0.064 & - & -0.053 \\
8. Education & 0.072 & 0.034 & -0.056 & 0.053 & -0.104 & -0.110 & - \\
9. Monthly income & -0.090 & 0.109 & -0.114 & -0.083 & $-.0134^{*}$ & $0.139^{*}$ & $0.262^{* *}$ & 0.093 \\
Mean & 4.143 & 4.018 & 4.439 & 4.604 & 4.322 & 0.47 & 26.92 & 2.15 \\
S.D. & 1.387 & 1.408 & 1.359 & 1.574 & 1.590 & 0.500 & 3.936 & 0.850 \\
\hline
\end{tabular}

Note: ${ }^{*} p<0.05,{ }^{* *} p<0.01$. The bold numbers in the diagonal row are the square roots of the AVE.

\subsection{Analytical Approach}

In calculating the degree of expectation (dis)confirmation, previous studies have often adopted a direct research view by either counting difference scores or directly measuring perceived disconfirmation [37]. Pertaining to the first approach, difference scores may (1) provide ambiguous and confounding results because the outcome variable is not clearly associated with expectation or experience; (2) cause an oversimplification of the results because the three-dimensional relationship between expectation and experience and the outcome variable is reduced to a two-dimensional one; and (3) impose untested constraints on the consistency equations [67]. Although the direct measurement approach attempts to avoid these problems, it incurs another major problem: the absolute levels of expectation and experience and the direction of the disconfirmation are not captured [37]. 
Considering the limitations of direct measurement in accurately detecting the effects of customer experiences consistency, the polynomial regression analysis introduced by Edwards and Parry [67] represents the latest in a line of studies to calculate (in)consistency and assess its impact [68].

In polynomial modeling, customer satisfaction (CS) is regressed on online customer experiences (ONCX), offline customer experiences (OFFCX), and three higher-order effects (i.e., $\mathrm{ONCX}^{2}$, OFFCX ${ }^{2}$ and $\mathrm{ONCX} \times \mathrm{OFFCX}$ ), after scale centering both ONCX and OFFCX (see Equation (1)). Following the steps of response surface analysis, the coefficients estimated in the polynomial modeling are used to calculate the slopes and curvatures (Edwards and Parry, 1993). For this study, we calculated the parameters along the consistency $(\mathrm{ONCX}=\mathrm{OFFCX})$ and inconsistency $(\mathrm{ONCX}=-\mathrm{OFFCX})$ lines as the consistency slope $\left(a_{1}+a_{2}\right)$, the consistency curvature $\left(a_{3}+a_{4}+a_{5}\right)$, the inconsistency slope $\left(a_{1}-a_{2}\right)$, and the inconsistency curvature $\left(a_{3}-a_{4}+a_{5}\right)$. To test the H1, the inconsistency curvature $\left(a_{3}-a_{4}+a_{5}\right)$ should be negative. To examine the $\mathrm{H} 2$, the consistency slope $\left(a_{1}+a_{2}\right)$ should be positive. To test the $\mathrm{H} 3$, the inconsistency slope $\left(a_{1}-a_{2}\right)$ should be negative.

$C S=a_{0}+a_{1} \times O N C X+a_{2} \times$ OFFCX $+a_{3} \times O_{O N C X}^{2}+a_{4} \times O N C X \times O F F C X+a_{5} \times O F F C X^{2}+e$

Following the block variable method $[68,69]$, we tested the indirect effects of customer experience (in)consistency on service success (H4). A block variable was computed as a weighted composite score through multiplying the raw data by the polynomial coefficients. Specifically, based on the result of Equation (1), the first block variable was computed with the weighted composite of $a_{1} \times$ ONCX $+a_{2} \times$ OFFCX $+a_{3} \times$ ONCX $X^{2}+a_{4} \times$ ONCX $\times$ OFFCX $+a_{5} \times$ OFFCX $X^{2}$. Then, the mediation variables (i.e., customer satisfaction) are regressed on the first block variable to get the path coefficient $(a)$. Similarly, the second block variable was computed with the weighted composite of $c_{1} \times$ ONCX $+c_{2} \times$ OFFCX + $c_{3} \times O_{N C X}^{2}+c_{4} \times O N C X \times O F F C X+c_{5} \times O F F C X^{2}$ according to the result of Equation (2) where $Y$ represents the outcome variables (i.e., repurchase intention, word-of-mouth). Then, we regressed the outcome variables (i.e., repurchase intention, word-of-mouth) on the second block variable $\left(c^{\prime}\right)$ and customer satisfaction $(b)$. The path coefficient of the second block variable $\left(c^{\prime}\right)$ represents the direct effect of customer experience (in)consistency on outcome variables (i.e., repurchase intention, word-of-mouth). The indirect effect was computed through multiplying the coefficient of first block variable on customer satisfaction and coefficient of customer satisfaction on outcome variables (i.e., $a \times b$ ). The significance of indirect effect was examined by the 95\% BC-CI (bias-corrected confidence interval) which was computed through bootstrapping 10,000 samples.

$$
Y=c_{0}+c_{1} \times O N C X+c_{2} \times O F F C X+c_{3} \times O N C X^{2}+c_{4} \times O N C X \times O F F C X+c_{5} \times O F F C X^{2}+c_{6} \times C S+e
$$

\section{Analysis and Results}

H1 predicted a consistency effect such that the greater the consistency between customers' online and offline experiences, the greater the customer satisfaction. As the result of Model 2 presented in Table 4, the curvature of the inconsistency line (ONCX $=-$ OFFCX) is significantly negative $\left(a_{3}-a_{4}+a_{5}=-0.320, p<0.01\right)$, demonstrating that the higher customer satisfaction results from the equivalent between online and offline customer experiences, and any deviations from the consistency line $(\mathrm{ONCX}=\mathrm{OFFCX})$ are associated with lower customer satisfaction. In sum, H1 was supported. 
Table 4. Polynomial regression results.

\begin{tabular}{|c|c|c|c|c|c|c|c|c|}
\hline \multirow{2}{*}{ Variables } & \multicolumn{2}{|c|}{ Customer Satisfaction } & \multicolumn{3}{|c|}{ Repurchase Intention } & \multicolumn{3}{|c|}{ Word-of-Mouth } \\
\hline & Model 1 & Model 2 & Model 3 & Model 4 & Model 5 & Model 6 & Model 7 & Model 8 \\
\hline Constant & $4.534^{* * *}$ & $4.672 * * *$ & $4.461^{* * *}$ & $4.405^{* * *}$ & $2.212 * * *$ & $4.720 * * *$ & $4.839 * * *$ & $2.164^{* * *}$ \\
\hline Gender & $0.522^{* *}$ & $449^{* *}$ & 0.112 & 0.036 & -0.175 & 0.101 & -0.037 & -0.294 * \\
\hline Age & 0.005 & 0.003 & 0.005 & 0.009 & 0.008 & 0.013 & 0.010 & 0.009 \\
\hline Education & -0.033 & -0.066 & 0.123 & 0.062 & 0.093 & -0.160 & $-0.237^{*}$ & -0.199 * \\
\hline Monthly income & -0.166 & -0.145 & -0.133 & $-0.161 *$ & -0.093 & $-0.190 *$ & -0.109 & -0.027 \\
\hline $\begin{array}{l}\text { Online customer } \\
\text { experiences (ONCX) }\end{array}$ & & 0.015 & & $0.274^{* *}$ & $0.267^{* *}$ & & $0.340^{* * *}$ & $0.331^{* * *}$ \\
\hline $\begin{array}{l}\text { Offline customer } \\
\text { experiences (OFFCX) }\end{array}$ & & $0.348^{* * *}$ & & $-0.204^{*}$ & 0.041 & & $0.215^{*}$ & 0.015 \\
\hline $\mathrm{ONCX}^{2}$ & & $-0.231^{* * *}$ & & 0.070 & $0.179 * *$ & & -0.177 * & -0.045 \\
\hline ONCX $\times$ OFFCX & & $0.195^{* * *}$ & & -0.026 & -0.118 & & $0.175^{*}$ & 0.064 \\
\hline OFFCX $^{2}$ & & $0.105^{*}$ & & 0.015 & -0.035 & & 0.053 & -0.007 \\
\hline Customer satisfaction & & & & & $0.469^{* * *}$ & & & $0.573^{* * *}$ \\
\hline $\begin{array}{l}R^{2} \\
\text { Consistency line } \\
(\text { ONCX }=\text { OFFCX })\end{array}$ & 0.051 & 0.309 & 0.012 & 0.186 & 0.300 & 0.028 & 0.349 & 0.514 \\
\hline Slope & & $0.364^{* * *}$ & & $0.479^{* * *}$ & $0.308^{* *}$ & & $0.555^{* * *}$ & $0.347^{* *}$ \\
\hline Curvature & & 0.069 & & 0.059 & 0.026 & & 0.051 & 0.011 \\
\hline $\begin{array}{l}\text { Inconsistency line } \\
(\mathrm{ONCX}=-\mathrm{OFFCX})\end{array}$ & & & & & & & & \\
\hline Slope & & -0.333 * & & 0.070 & 0.227 & & 0.125 & 0.316 \\
\hline Curvature & & $-0.320 * *$ & & 0.111 & 0.262 & & $-0.300 *$ & -0.116 \\
\hline
\end{tabular}

Notes: ${ }^{*} p<0.05,{ }^{* *} p<0.01,{ }^{* * *} p<0.001$.

$\mathrm{H} 2$ predicted that the high level consistent between online and offline customer experiences produce higher customer satisfaction than the low level consistent. As the result of Model 2 shown in Table 4, the slope of the consistency line (ONCX $=$ OFFCX) was significant and positive $\left(a_{1}+a_{2}=0.364, p<0.001\right)$, suggesting that the high-high consistency condition was associated with higher customer satisfaction than the low-low consistency condition. Thus, these results suggest support for $\mathrm{H} 2$.

$\mathrm{H} 3$ proposed an asymmetrical inconsistency effect such that customer satisfaction is lower when customers perceive better online experiences than offline ones compared to when customers perceive better offline experiences than online ones. This reflects the significant negative slope of the inconsistency line (ONCX $=-\mathrm{OFFCX})$. The result of Model 2 in Table 4 shows that the slope for the inconsistency line (ONCX $=-$ OFFCX) was negatively significant $\left(a_{1}-a_{2}=0.333, p<0.05\right)$, thus supporting H3.

$\mathrm{H} 4$ predicted that the mediation role of customer satisfaction in the relationship between customer experience (in)consistency and service outcomes (i.e., repurchase intention, word-of-mouth). As presented in Table 5, the effect of customer experience (in)consistency on customer satisfaction $(a=0.510, p<0.001)$ was significant. The impacts of customer satisfaction on repurchase intention $(b=0.405, p<0.001)$ and on word-of-mouth ( $b=0.489, p<0.001)$ both were significant and positive, as predicted. The indirect effect between customer experience (in)consistency and repurchase intention that was carried through customer satisfaction was 0.207 and significant (95\% BC-CI [0.131, 0.305]), supporting H4a. The indirect effect between customer experience (in)consistency and wordof-mouth that was carried through customer satisfaction was 0.249 and significant $(95 \%$ BC-CI $[0.179,0.335])$, supporting H4b. In addition, the direct impacts of customer experience (in)consistency on repurchase intention $\left(c^{\prime}=0.304, p<0.001\right)$ and word-of-mouth $\left(c^{\prime}=0.344, p<0.001\right)$ were significant, which indicates that the influence of customer experience (in)consistency on service outcomes (i.e., repurchase intention, word-of-mouth) is partially mediated by customer satisfaction. Total effect includes the direct and indirect effect. Thus, the total effect of customer experience (in)consistency on repurchase intention 
was 0.511 . Similarly, the total effect of customer experience (in)consistency on repurchase intention was 0.593 .

Table 5. Indirect and direct effects of customer experience (in)consistency on service outcomes.

\begin{tabular}{llll}
\hline Variables & Customer Satisfaction & Repurchase Intention & Word-of-Mouth \\
\hline Coefficient of the block variable & $0.510^{* * *}(a)$ & $0.304^{* * *}\left(c^{\prime}\right)$ & $0.344^{* * *}\left(c^{\prime}\right)$ \\
Coefficient of customer satisfaction & & $0.405^{* * *}(b)$ & $0.489^{* * *}(b)$ \\
Indirect effect $(\boldsymbol{a} \times \boldsymbol{b})$ & 0.207 & 0.249 \\
$95 \%$ BC-CI for the indirect effect & & {$[0.131,0.305]$} & {$[0.179,0.335]$} \\
\hline
\end{tabular}

Notes: ${ }^{* * *} p<0.001$

\section{Conclusions}

The arrival of digital technologies is reshaping firms' retail practices and customer purchase journeys. The boundaries between different retail channels have blurred and faded away, and omni-channel customers often simultaneously use offline and online channels to minimize their inputs and optimize their purchase decisions [44,45]. However, omni-channel retailers implementing customer experience management programs still face a vital challenge: how to balance and manage the omni-channel customer experience (in)consistency to achieve service success [28]. Our study examines how various combinations of online and offline customer experiences differ in driving customer satisfaction and ultimate service success.

The results first reveal that consistency between a customer's online and offline channel experience is generally better than omni-channel customer experience inconsistency for obtaining customer satisfaction, word-of-mouth, and repurchase intention. In addition, higher levels of customer experience consistency are superior to lower levels for achieving service success. These results align with those of most previous studies $[1,23]$ in predicting positive outcomes from omni-channel customer experience consistency.

Unexpectedly, enlightened by the polynomial regression approach, our results also disclose several more nuanced findings on the three-dimensional relationship among online customer experience, offline customer experience, and service outcomes. First, when implemented separately, the online and offline customer experiences exhibit diverse effects: offline customer experience is more effective in improving customer satisfaction, while online customer experience is more effective in influencing repurchase intention and wordof-mouth (see Models 2, 5, and 8 in Table 4). These results help to consummate the research of Gao et al. [70], which proposes that customer experience quality is always beneficial to performance outcomes. By differentiating online and offline channels, this study uncovers the distinct effectiveness of multichannel customer experience on service performance.

Second, when the qualities of online and offline customer experience are inconsistent, the offline high-quality/online low-quality configuration is always more helpful than the online high-quality/offline low-quality configuration for improving customer satisfaction. These findings complement the research design of Gao et al. [28] by interpreting the significant difference between the two directions of inconsistency. All of these results reinforce the importance of customer experience consistency in omni-channel retailing practices. Thus, this study not only provides new evidence into the customer experience literature but also provides practical guidance for customer experience management programs.

\section{Discussion}

\subsection{Theoretical Implications}

This study sought to connect two domains of customer experience research-offline and online retailing settings, which not only answers the call of Lemon and Verhoef [5] to go beyond the widely available channel choice models and develop an omni-channel understanding of customer experience but also echoes the call of Rose et al. [20] (p. 26), that "given the existence today of two retail contexts, i.e., face-to-face (termed offline) and internet based (termed online), a comparison of the two is called for." By integrating 
customers' online and offline experiences toward a certain brand and examining how the effectiveness of customer experiences from different retail channels may be subject to one another, this research contributes to advance the literatures on customer experience. The findings help to clearly describe the customer experience in the omnichannel setting, thus fertilizing the understanding of customer experience.

Second, our study makes a great contribution to the channel consistency research through including an indirect research view to capture omni-channel customer experience (in)consistency. In doing so, we answer the call of Landers et al. [34] (p. 385) to "examine alternative conceptualizations and measurements for incongruity". Drawing on polynomial regression and response surface analysis, we measure online and offline customer experiences separately, categorize omni-channel customer experience (in)consistency into four dimensions, and scrutinize the relative effectiveness of customer experience in these categories. Our results show that in driving positive customer outcomes, customer experience consistency is consistently superior to customer experience inconsistency, consistent high quality is superior to consistent low quality, and customer experience inconsistency where offline experiences are better is superior to customer experience inconsistency where online experiences are better. These results not only support the notion that polynomial regression represents the latest in a line of studies that calculate (in)consistency [68] but also suggest the significance of matching online and offline customer experience. As such, the dyadic perspective on omni-channel customer experiences provides new insight into channel consistency research.

Third, our research contributes to EDT via shedding light on the distinction between the effects of the two expectation disconfirmation directions. In doing so, we answer the call of Badrinarayanan et al. [33] (p. 552): although "some erstwhile online retailers have begun to initiate brick-and-mortar operations, the proposed framework ... need[s] to be examined to verify whether the directionality of congruence ... matter[s]." Our research also confirms the propositions of Goode et al. [36] by testing the slope of the inconsistency line and differentiating the directions of disconfirmation, thus extending our understanding of customer experience inconsistency. The results indicate that the inconsistency between a higher quality of online customer experience and a lower quality of offline customer experience is more detrimental than the inconsistency between a higher quality of offline customer experience and a lower quality of online customer experience (see Table 4).

\subsection{Practical Implications}

The effectiveness of customer experience in driving service success is an important issue that concerns all practitioners, including brands implementing omni-channel strategies and sales and service managers involved in customer experience management programs [14]. Our answers to our two research questions reveal several significant implications for practitioners regarding the design of seamless and consistent retail channels and for the optimization of omni-channel customer experiences.

In answering the first research question, "how does omni-channel customer experience (in)consistency influence brands' and retail companies' service success?", we concur with Huré et al. [1] (p. 316) that "perceived consistency, defined as the consumers' perceived coherence of the retailing mix of touch points, is expected by consumers". According to the results of our study, compared with omni-channel inconsistency, customers expect consistent experiences across offline and online retail channels. Therefore, regarding instore and website/app layouts, practitioners (e.g., marketing heads, brand marketing managers) should note the challenge of keeping both layouts consistent to give customers a consistent experience in their cross-channel journey [35]. Retail managers involved in customer experience management programs must therefore be aware that each touch point between customers and brands is important, and thus attention to all retail channels is necessary to achieve maximal service success [14].

In addition, we echo Kim and Choi's [18] (p. 394) notion that "enhancing customer experience quality is critical to engendering customer citizenship behavior". The findings 
of our study show that compared with omni-channel customer experience consistency at a lower level, customers prefer the consistency of customer experiences at a higher level. Therefore, brand marketing managers and retail managers should recognize that both the quality and the balance of omni-channel customer experience are vital for determining customers' choice. Further, because a critical challenge exists in allocating and distributing resources to different channels throughout the retail channel design process, the support from the top management should be valued. Executives might emphasize retail channel design as a matter of firm-wide deployment and use their oversight to guide the development of a benign and balanced retail channel system, which can induce high level of customer satisfaction.

Our second research question is, "what kind of omni-channel customer experience inconsistency should brands and retail companies address to avoid service failure?" We caution practitioners against the excessive development of online retail channels. The literature suggests that, in the online shopping environment, the superior customer experience can lead to customers' greater revisiting intention, continuance intention, and loyalty $[54,71]$, and many firms nowadays are devoting most of their marketing investment to create optimal customer experience through online channels [19]. However, the research results highlight the detrimental effects of a customer's having a better online than offline experience with a certain brand. As illustrated by Huré et al. [1] (p. 321), "any failure to meet these expectations (e.g., consistency of an omni-channel experience) is negatively perceived and is resented by consumers. Consumers particularly perceive such inconstancies when they are in physical stores." Therefore, we suggest that to avoid service failure, brands should first ensure quality customer experience in offline retail channels rather than overinvest in online retail channels.

\subsection{Limitations and Future Research Lines}

First, we used a survey method to collect data from customers to examine our model. Although our model testing yielded results consistent with the hypothesized relationships, our cross-sectional sample may constrain our ability to make causal inferences. Future work could adopt a longitudinal design to validate the causal relationship between omnichannel customer experience and service outcomes. Second, this research was conducted in China. This may limit our findings' generalizability. In this sense, our findings on the effectiveness of omni-channel customer experience (in)consistency may not hold in other countries. Future research could test our hypotheses in other cultural backgrounds. Third, this study only examined the mediation role of customer satisfaction. Future studies should consider other mediation variables to explore the effects of customer experience (in)consistency more deeply.

Author Contributions: Conceptualization, W.G. and H.F.; methodology, W.G. and H.F.; software, W.G.; validation, W.G. and H.F.; formal analysis, W.G.; investigation, W.G.; resources, W.G. and H.F.; data curation, W.G.; writing—original draft preparation, H.F.; writing—review and editing, W.G. and H.F.; visualization, H.F.; supervision, W.G.; project administration, W.G.; funding acquisition, W.G. and H.F. Both authors have read and agreed to the published version of the manuscript.

Funding: This research was funded by the Chongqing Social Science Planning Project (2020BS60), the Fundamental Research Funds for the Central Universities (SWU2109521), and the Innovative Research Team of Shanghai International Studies University (2020114047).

Institutional Review Board Statement: Not applicable.

Informed Consent Statement: Informed consent was obtained from all subjects involved in the study.

Data Availability Statement: The data presented in this study are available in the article.

Conflicts of Interest: The authors declare no conflict of interest. 


\section{References}

1. Huré, E.; Picot-Coupey, K.; Ackermann, C.L. Understanding omni-channel shopping value: A mixed-method study. J. Retail. Consum. Serv. 2017, 39, 314-330. [CrossRef]

2. Barwitz, N.; Maas, P. Understanding the omnichannel customer journey: Determinants of interaction choice. J. Interact. Mark. 2018, 43, 116-133. [CrossRef]

3. Lee, W.J. Unravelling consumer responses to omni-channel approach. J. Theor. Appl. Electron. Commer. Res. 2020, 15, 37-49. [CrossRef]

4. Flavián, C.; Gurrea, R.; Orús, C. Combining channels to make smart purchases: The role of webrooming and showrooming. J. Retail. Consum. Serv. 2020, 52, 101923. [CrossRef]

5. Lemon, K.N.; Verhoef, P.C. Understanding customer experience throughout the customer journey. J. Mark. 2016, 80, 69-96. [CrossRef]

6. McKinsey. Digital China: Powering the Economy to Global Competitiveness. 2017. Available online: www.mckinsey.com/ featured-insights / china / digital-china-powering-the-economy-to-global-competitiveness (accessed on 1 August 2019).

7. Shi, S.; Wang, Y.; Chen, X.; Zhang, Q. Conceptualization of omnichannel customer experience and its impact on shopping intention: A mixed-method approach. Int. J. Inf. Manag. 2020, 50, 325-336. [CrossRef]

8. Hsia, T.L.; Wu, J.H.; Xu, X.; Li, Q.; Peng, L.; Robinson, S. Omnichannel retailing: The role of situational involvement in facilitating consumer experiences. Inf. Manag. 2020, 57, 103390. [CrossRef]

9. Gao, W.; Fan, H.; Li, W.; Wang, H. Crafting the customer experience in omnichannel contexts: The role of channel integration. J. Bus. Res. 2021, 126, 12-22. [CrossRef]

10. Verhoef, P.C.; Lemon, K.N.; Parasuraman, A.; Roggeveen, A.; Tsiros, M.; Schlesinger, L.A. Customer experience creation: Determinants, dynamics and management strategies. J. Retail. 2009, 85, 31-41. [CrossRef]

11. Kim, H.; Choi, B. The influence of customer experience quality on customers' behavioral intentions. Serv. Mark. Q. 2013, 34, 322-338. [CrossRef]

12. Roggeveen, A.L.; Grewal, D.; Schweiger, E.B. The DAST framework for retail atmospherics: The impact of in-and out-of-store retail journey touchpoints on the customer experience. J. Retail. 2020, 96, 128-137. [CrossRef]

13. Barbu, C.M.; Florea, D.L.; Dabija, D.C.; Barbu, M.C.R. Customer Experience in Fintech. J. Theor. Appl. Electron. Commer. Res. 2021, 16, 1415-1433. [CrossRef]

14. Homburg, C.; Jozić, D.; Kuehnl, C. Customer experience management: Toward implementing an evolving marketing concept. J. Acad. Mark. Sci. 2017, 45, 377-401. [CrossRef]

15. McColl-kennedy, J.R.; Zaki, M.; Lemon, K.N.; Urmetzer, F.; Neely, A. Gaining Customer Experience In-sights That Matter. J. Serv. Res. 2019, 22, 8-26. [CrossRef]

16. Siebert, A.; Gopaldas, A.; Lindridge, A.; Simões, C. Customer experience journeys: Loyalty loops versus involvement spirals. J. Mark. 2020, 84, 45-66. [CrossRef]

17. Dennis, C.; Brakus, J.J.; Gupta, S.; Alamanos, E. The effect of digital signage on shoppers' behavior: The role of the evoked experience. J. Bus. Res. 2014, 67, 2250-2257. [CrossRef]

18. Kim, H.S.; Choi, B. The effects of three customer-to-customer interaction quality types on customer experience quality and citizenship behavior in mass service settings. J. Serv. Mark. 2016, 30, 384-397. [CrossRef]

19. McLean, G.; Al-Nabhani, K.; Wilson, A. Developing a mobile applications customer experience model (MACE)—Implications for retailers. J. Bus. Res. 2018, 85, 325-336. [CrossRef]

20. Rose, S.; Hair, N.; Clark, M. Online customer experience: A review of the business-to-consumer online purchase context. Int. J. Manag. Rev. 2011, 13, 24-39. [CrossRef]

21. Barari, M.; Ross, M.; Surachartkumtonkun, J. Negative and positive customer shopping experience in an online context. J. Retail. Consum. Serv. 2020, 53, 1-9. [CrossRef]

22. Ma, L.; Zhang, X.; Ding, X.; Wang, G. How Social Ties Influence Customers' Involvement and Online Purchase Intentions. J. Theor. Appl. Electron. Commer. Res. 2021, 16, 395-408. [CrossRef]

23. Verhoef, P.C.; Kannan, P.K.; Inman, J.J. From multi-channel retailing to omni-channel retailing: Introduction to the special issue on multi-channel retailing. J. Retail. 2015, 91, 174-181. [CrossRef]

24. Bueno, E.V.; Weber, T.B.; Bomfim, E.L.; Kato, H.T. Measuring customer experience in service: A systematic review. Serv. Ind. J. 2019, 39, 779-798. [CrossRef]

25. Bawack, R.E.; Wamba, S.F.; Carillo, K.D.A. Exploring the role of personality, trust, and privacy in customer experience performance during voice shopping: Evidence from SEM and fuzzy set qualitative comparative analysis. Int. J. Inf. Manag. 2021, 58, 102309. [CrossRef]

26. Verhoef, P.C.; Neslin, S.A.; Vroomen, B. Multichannel customer management: Understanding the re-search-shopper phenomenon. Int. J. Res. Mark. 2007, 24, 129-148. [CrossRef]

27. Chen, Y.; Cheung, C.M.; Tan, C.W. Omnichannel business research: Opportunities and challenges. Decis. Support. Syst. 2018, 109, 1-4. [CrossRef]

28. Gao, W.; Li, W.; Fan, H.; Jia, X. How customer experience incongruence affects omnichannel customer retention: The moderating role of channel characteristics. J. Retail. Consum. Serv. 2021, 60, 102487. [CrossRef] 
29. Kopot, C.; Cude, B.J. Channel depth or consistency? A study on establishing a sustainable omnichannel strategy for fashion department store retailers. Sustainability 2021, 13, 6993. [CrossRef]

30. Lee, Z.W.Y.; Chan, T.K.H.; Chong, A.Y.-L.; Thadani, D.R. Customer engagement through omnichannel retailing: The effects of channel integration quality. Ind. Mark. Manag. 2019, 77, 90-101. [CrossRef]

31. Blom, A.; Lange, F.; Hess, R.L., Jr. Omnichannel-based promotions' effects on purchase behavior and brand image. J. Retail. Consum. Serv. 2017, 39, 286-295. [CrossRef]

32. Sohn, S. Consumer processing of mobile online stores: Sources and effects of processing fluency. J. Retail. Consum. Serv. 2017, 36, 137-147. [CrossRef]

33. Badrinarayanan, V.; Becerra, E.P.; Kim, C.H.; Madhavaram, S. Transference and congruence effects on purchase intentions in online stores of multi-channel retailers: Initial evidence from the US and South Korea. J. Acad. Mark. Sci. 2012, 40, 539-557. [CrossRef]

34. Landers, V.M.; Beatty, S.E.; Wang, S.; Mothersbaugh, D.L. The effect of online versus offline retailer-brand image incongruity on the flow experience. J. Mark. Theory Pract. 2015, 23, 370-387. [CrossRef]

35. Picot-Coupey, K.; Huré, E.; Piveteau, L. Channel design to enrich customers' shopping experiences: Synchronizing clicks with bricks in an omni-channel perspective-The direct optic case. Int. J. Retail. Distrib. Manag. 2016, 44, 336-368. [CrossRef]

36. Goode, S.; Hoehle, H.; Venkatesh, V.; Brown, S.A. User compensation as a data breach recovery action: An investigation of the Sony PlayStation Network breach. MIS Q. 2017, 41, 703-727. [CrossRef]

37. Venkatesh, V.; Goyal, S. Expectation disconfirmation and technology adoption: Polynomial modeling and response surface analysis. MIS Q. 2010, 34, 281-303. [CrossRef]

38. Piercy, N. Positive and negative cross-channel shopping behaviour. Mark. Intell. Plan. 2012, 30, 83-104. [CrossRef]

39. Montoya-Weiss, M.M.; Voss, G.B.; Grewal, D. Determinants of online channel use and overall satisfaction with a relational, multichannel service provider. J. Acad. Mark. Sci. 2003, 31, 448-458. [CrossRef]

40. Kwon, W.S.; Lennon, S.J. Reciprocal effects between multichannel retailers' offline and online brand images. J. Retail. 2009, 85, 376-390. [CrossRef]

41. Le, A.N.H.; Nguyen-Le, X.-D. A moderated mediating mechanism of omnichannel customer experiences. Int. J. Retail. Distrib. Manag. 2021, 49, 595-615. [CrossRef]

42. Pekovic, S.; Rolland, S. Recipes for achieving customer loyalty: A qualitative comparative analysis of the dimensions of customer experience. J. Retail. Consum. Serv. 2020, 56, 102171. [CrossRef]

43. Rather, R.A. Customer experience and engagement in tourism destinations: The experiential marketing perspective. J. Travel Tour. Mark. 2020, 37, 15-32. [CrossRef]

44. Orús, C.; Gurrea, R.; Ibáñez-Sánchez, S. The impact of consumers' positive online recommendations on the omnichannel webrooming experience. Span. J. Mark. ESIC 2019, 23, 397-414. [CrossRef]

45. Flavián, C.; Gurrea, R.; Orús, C. Mobile word of mouth (m-WOM): Analysing its negative impact on webrooming in omnichannel retailing. Int. J. Retail. Distrib. Manag. 2020, 49, 394-420. [CrossRef]

46. Flavián, C.; Gurrea, R.; Orús, C. Feeling confident and smart with webrooming: Understanding the consumer's path to satisfaction. J. Interact. Mark. 2019, 47, 1-15. [CrossRef]

47. Lankton, N.K.; McKnight, D.H.; Wright, R.T.; Thatcher, J.B. Research note-Using expectation disconfirmation theory and polynomial modeling to understand trust in technology. Inf. Syst. Res. 2016, 27, 197-213. [CrossRef]

48. Bhattacherjee, A.; Premkumar, G. Understanding changes in belief and attitude toward information technology usage: A theoretical model and longitudinal test. MIS Q. 2004, 28, 229-254. [CrossRef]

49. Lankton, N.K.; McKnight, H.D. Examining two expectation disconfirmation theory models: Assimilation and asymmetry effects. J. Assoc. Inf. Syst. 2012, 13, 88-115. [CrossRef]

50. Roldán Bravo, M.I.; Lloréns Montes, F.J.; Ruiz Moreno, A. Open innovation in supply networks: An expectation disconfirmation theory perspective. J. Bus. Ind. Mark. 2017, 32, 432-444. [CrossRef]

51. Mosteller, J.R.; Donthu, N.; Eroglu, S. The fluent online shopping experience. J. Bus. Res. 2014, 67, 2486-2493. [CrossRef]

52. Kazancoglu, I.; Aydin, H. An investigation of consumers' purchase intentions towards omni-channel shopping. Int. J. Retail. Distrib. Manag. 2018, 46, 959-976. [CrossRef]

53. Elliot, A.J.; Devine, P.G. On the motivational nature of cognitive dissonance: Dissonance as psychological discomfort. J. Pers. Soc. Psychol. 1994, 67, 382-394. [CrossRef]

54. Lee, H.S.S.; Balaji, M.S.; Khong, K.W. An investigation of online shopping experience on trust and behavioral intentions. J. Internet Commer. 2015, 14, 233-254.

55. Bustamante, J.C.; Rubio, N. Measuring customer experience in physical retail environments. J. Serv. Manag. 2017, $28,884-913$. [CrossRef]

56. Lankton, N.K.; Wilson, E.V.; Mao, E. Antecedents and determinants of information technology habit. Inf. Manag. 2010, 47, 300-307. [CrossRef]

57. Wang, F.; Head, M. How can the web help build customer relationships? An empirical study on e-tailing. Inf. Manag. 2007, 44, 115-129. [CrossRef]

58. Hassanein, K.; Head, M. Manipulating perceived social presence through the web interface and its impact on attitude towards online shopping. Int. J. Hum. Comput. St. 2007, 65, 689-708. [CrossRef] 
59. Szajna, B.; Scamell, R.W. The effects of information system user expectations on their performance and perceptions. MIS Q. 1993, 17, 493-516. [CrossRef]

60. Brown, S.A.; Venkatesh, V.; Goyal, S. Expectation confirmation in information systems research: A test of six competing models. MIS Q. 2014, 38, 729-756. [CrossRef]

61. Baker, J.; Parasuraman, A.; Grewal, D.; Voss, G.B. The influence of multiple store environment cues on perceived merchandise value and patronage intentions. J. Mark. 2002, 66, 120-141. [CrossRef]

62. Ranaweera, C.; Karjaluoto, H. The impact of service bundles on the mechanism through which functional value and price value affect WOM intent. J. Serv. Manag. 2017, 28, 707-723. [CrossRef]

63. Pérez, A.; Rodriguez del Bosque, I. Corporate social responsibility and customer loyalty: Exploring the role of identification, satisfaction and type of company. J. Serv. Mark. 2015, 29, 15-25. [CrossRef]

64. Khalifa, M.; Liu, V. Online consumer retention: Contingent effects of online shopping habit and online shopping experience. Eur J. Inf. Syst. 2007, 16, 780-792. [CrossRef]

65. Fornell, C.; Larcker, D.F. Evaluating structural equation models with unobservable variables and measurement error. J. Mark. Res. 1981, 18, 39-50. [CrossRef]

66. Lindell, M.K.; Whitney, D.J. Accounting for common method variance in cross-sectional research de-signs. J. Appl. Psychol. 2001, 86, 114-121. [CrossRef] [PubMed]

67. Edwards, J.R.; Parry, M.E. On the use of polynomial regression equations as an alternative to difference scores in organizational research. Acad. Manag. J. 1993, 36, 1577-1613.

68. Edwards, J.R.; Cable, D.M. The value of value congruence. J. Appl. Psychol. 2009, 94, 654-677. [CrossRef] [PubMed]

69. Wong, S.I.; Giessner, S.R. The thin line between empowering and laissez-faire leadership: An expectancy-match perspective. J. Manag. 2018, 44, 757-783. [CrossRef]

70. Gao, L.; Melero-Polo, I.; Sese, F.J. Customer equity drivers, customer experience quality, and customer profitability in banking services: The moderating role of social influence. J. Serv. Res. 2020, 23, 174-193. [CrossRef]

71. Dai, B.; Forsythe, S.; Kwon, W.S. The impact of online shopping experience on risk perceptions and online purchase intentions: Does product category matter? J. Electron. Commer. Res. 2014, 15, 13-24. 